\title{
Evaluation of meals cooked by large-scale methods: a comparison of chemical analysis and calculation from food tables
}

\author{
By ANNE I. STOCK \\ Nutrition Department, Queen Elizabeth College, London $W 87 A H$ \\ AND ERICA F. WHEELER \\ Department of Human Nutrition, \\ London School of IIygiene and Tropical Medicine, London $W_{\mathrm{I}}{ }_{7} H T$
}

(Received 3 August 1971 - Accepted I3 September 1971)

\begin{abstract}
I. Energy, protein, fat and iron have been determined by chemical analysis in a number of meals and whole days' diets prepared by large-scale catering methods. 'Ihe results have been compared with the results of calculation from food composition tables.

2. There were wide differences between calculated and analytical values for all the constituents, especially for fat and iron. For energy and fat, calculation from food tables gave constantly higher results than did analysis.

3. Large differences in calculated and analysed fat and energy intakes occurred especially when there was frequent use of certain foods that are generally prepared in a non-standard way.

4. The range of differences between average calculated and analytical results depended on the duration of surveys. We have estimated that in a $7 \mathrm{~d}$ survey, calculated $7 \mathrm{~d}$ protein and energy intakes would fall within $\pm 20 \%$ of the analytical value in $90 \%$ of individuals; for iron and probably for other minerals, the range would be $\pm 50 \%$ of the analytical value.
\end{abstract}

One method used for estimating the nutrient intake of groups or individuals is to weigh the amount of food eaten and to calculate its nutritive value from food composition tables. It is assumed that the error introduced by their use is small or consistent enough for valid comparisons to be made between the intakes of different groups, or between group intakes and some standardized estimate of requirement.

A number of workers have investigated discrepancies between calculated and analysed nutrient intakes. Whiting \& Leverton (1960) summarized some 300 of these comparisons (see 'lable $\mathrm{I}$ ); their data included figures from the USA, Britain and Canada, and cover a wide range of precision in meal preparation methods. 'The food composition table most used in the $\mathrm{CK}$ is probably The Composition of Foods (McCance \& Widdowson, 1960), and calculations using this table have been checked with analysis figures for metabolic ward diets (Widdowson \& McCance, 1943), for diets in childrens' homes containing not more than twenty children (Bransby, Daubney \& King, $194^{8-}$ $9 a$ ), and for domestic diets (Bransby, Daubney \& King, r948-9b) (see Table r). These studies however, relate to food preparation on a small scale and, in one instance, to the careful procedure of a metabolic ward kitchen.

In practice, food tables are sometimes used to calculate the intake of people whose meals are cooked in large kitchens with large-scale methods and equipment. Examples are schoolchildren, hospital staff and patients, hostel residents, residents in 
Local Authority Homes and old people receiving Meals on Wheels. The recipes used in large-scale catering are often different, both in ingredients and proportions, from those used by housewives, and the duration of cooking time and time before serving may vary considerably, leading to variation in water content and in the retention of water-soluble and heat-labile nutrients. It is therefore necessary to know whether the error involved in the use of food tables is the same for institutional meals cooked on a large scale as it is for domestic and metabolic ward cooking. This has been investigated by workers in Poland and Japan (Krauze, Bożyk \& Zaniewska, 1965; Takagi \& Sato, 1969), and we have now made the comparison for some British diets.

Table I. Published data on the distribution of differences between calculated ( $c$ ) and analytical (a) values for the nutrient value of meals and diets

\begin{tabular}{|c|c|c|c|c|c|c|c|c|}
\hline \multirow{2}{*}{\multicolumn{2}{|c|}{$\begin{array}{c}\text { Ref- } \\
\text { Nutrient erence }\end{array}$}} & \multirow[b]{2}{*}{ Type of diet } & \multicolumn{4}{|c|}{$\begin{array}{l}\text { No. and } \% \text { of diets analysed falling within } \\
\text { each range of } \% \text { difference }\left(\frac{c-a}{a} \times \text { roo }\right)\end{array}$} & \multirow{2}{*}{$\begin{array}{l}\text { Total } \\
\text { no. in } \\
\text { group }\end{array}$} & \multirow{2}{*}{$\begin{array}{c}\text { Corre- } \\
\text { lation } \\
\text { coeff- } \\
\text { cient } \\
(c \text { v. } a)\end{array}$} \\
\hline & & & $0-9 \%$ & $10-19 \%$ & $\begin{array}{l}\text { All over } \\
10 \%\end{array}$ & $\begin{array}{l}\text { All over } \\
20 \%\end{array}$ & & \\
\hline \multirow[t]{4}{*}{$\begin{array}{l}\text { Energy } \\
(\mathrm{kcal})\end{array}$} & $\mathbf{I}$ & $\begin{array}{l}\text { Mixed: meals } \\
\text { and days' intakes }\end{array}$ & $218(58 \%)$ & - & $160(42 \%)$ & - & 378 & - \\
\hline & 2 & $\begin{array}{l}\text { Days' intakes, } \\
\text { domestic (children } \\
\text { in 'family' homes) }\end{array}$ & ${ }^{16(33 \%)}$ & $25(51 \%)$ & $33(67 \%)$ & $8(16 \%)$ & 49 & 0.87 \\
\hline & 3 & $\begin{array}{l}\text { Days' intakes, } \\
\text { domestic }\end{array}$ & $27(82 \%)$ & $5(15 \%)$ & $6(18 \%)$ & I $(3 \%)$ & 33 & - \\
\hline & $\begin{array}{l}4 \\
5\end{array}$ & $\begin{array}{l}\text { Single meals } \\
\text { Canteen meals }\end{array}$ & ${ }^{4}-$ & ${ }^{6}-$ & ${ }^{12}-$ & ${ }^{6}-$ & 16 & $0 . \overline{85}$ \\
\hline $\begin{array}{l}\text { Protein } \\
(\mathrm{g})\end{array}$ & $\begin{array}{l}\text { I } \\
2 \\
3 \\
6 \\
7 \\
5\end{array}$ & $\begin{array}{l}\text { Mixed } \\
\text { Domestic } \\
\text { Domestic } \\
\text { Metabolic diets } \\
\text { Metabolic diets } \\
\text { Canteen meals }\end{array}$ & $\begin{array}{l}\text { I70 }(54 \%) \\
29(60 \%) \\
17(51 \%) \\
4 \\
81(84 \%) \\
-\end{array}$ & $\begin{array}{l}- \\
19(39 \%) \\
13(40 \%) \\
2 \\
13(14 \%) \\
-\end{array}$ & $\begin{array}{c}\text { I48 (46\%) } \\
20(40 \%) \\
16(49 \%) \\
2 \\
15(16 \%) \\
-\end{array}$ & $\begin{array}{l}\overline{1}(2 \%) \\
3(9 \%) \\
0 \\
2(2 \%) \\
\end{array}$ & $\begin{array}{r}318 \\
49 \\
33 \\
6 \\
96 \\
\end{array}$ & $\begin{array}{l}\frac{-}{0.92} \\
\frac{-}{-} \\
-59\end{array}$ \\
\hline Fat (g) & $\begin{array}{l}\mathrm{I} \\
2 \\
3 \\
6 \\
7 \\
4\end{array}$ & $\begin{array}{l}\text { Mixed } \\
\text { Domestic } \\
\text { Domestic } \\
\text { Metabolic diets } \\
\text { Metabolic diets } \\
\text { Single meals }\end{array}$ & $\begin{array}{l}66(25 \%) \\
12(25 \%) \\
18(54 \%) \\
6 \\
55(57 \%) \\
2\end{array}$ & $\begin{array}{l}8(16 \%) \\
8(24 \%) \\
0 \\
27(28 \%) \\
4\end{array}$ & $\begin{array}{l}\text { I93 }(75 \%) \\
37(75 \%) \\
15(46 \%) \\
0 \\
41(52 \%) \\
14\end{array}$ & $\begin{array}{l}\overline{(60 \%)} \\
29(60 \%) \\
7(21 \%) \\
0 \\
14(14 \%) \\
10\end{array}$ & $\begin{array}{r}259 \\
49 \\
33 \\
6 \\
96 \\
16\end{array}$ & $\begin{array}{l}- \\
0.57 \\
= \\
=\end{array}$ \\
\hline Iron (mg) & $\begin{array}{l}2 \\
3\end{array}$ & $\begin{array}{l}\text { Domestic } \\
\text { Domestic }\end{array}$ & $\begin{array}{l}12(25 \%) \\
1(3 \%)\end{array}$ & $\begin{array}{l}\text { II }(23 \%) \\
3(9 \%)\end{array}$ & $\begin{array}{l}37(75 \%) \\
\text { 3I }(97 \%)\end{array}$ & $\begin{array}{l}26(53 \%) \\
29(88 \%)\end{array}$ & $\begin{array}{l}49 \\
33\end{array}$ & 0.57 \\
\hline
\end{tabular}

References: (1) Whiting \& Leverton (1960), (2) Bransby et al. (1948-9a), (3) Bransby et al. (1948-9b), (4) Groover et al. (1967), (5) Takagi \& Sato (1969), (6) Widdowson \& McCance (1943), (7) Eagles et al. (1966).

\section{MATERIALS AND METHODS}

\section{Collection and analysis of samples}

The sources of our data are summarized in Table 2. In no instance was the kitchen which supplied the meals catering for less than fifty people. In each sample, up to $2 \mathrm{~h}$ could elapse between the cooking and service of food.

During the collection of sample meals for analysis, each food item was weighed, and samples were frozen immediately on collection. On thawing, inedible material was 
removed and weighed and the remainder homogenized, and a weighed portion was dried at $95-100^{\circ}$. Subsequent analyses were carried out on the dried material. Nitrogen was estimated by semi-micro-Kjeldahl digestion, followed by determination of ammonia in the digest by autoanalyser. Crude protein was calculated as $N \times 6.25$. Energy values were measured with a ballistic bomb calorimeter (Miller \& Payne, 1959). Fat was determined by the Soxhlet method and iron by the method of Wootton (1958) as modified by Hegarty (1966). Chemical score was estimated from total sulphur (Miller \& Donoso, 1963) by the method described by Pellett \& Eddy (1964). The calculation of nutrient intakes was carried out with a Fortran program (Pellett \& Wheeler, $19^{6} 5$ ) on the London University computer. The food composition data consisted largely of values taken from The Composition of Foods (McCance \& Widdowson, 1960), supplemented by data from manufacturers of food products, and values for some cooked dishes calculated from recipes. Amino acid values were taken from the table of Orr \& Watt (1967).

Table 2. Meals and diets analysed for the comparison

\begin{tabular}{|c|c|c|c|c|}
\hline Series & Source & Type & $\begin{array}{c}\text { No. } \\
\text { analysed }\end{array}$ & Analyses done \\
\hline $\mathbf{S}$ & $\begin{array}{l}\text { Welfare meals supplied to old } \\
\text { peoples' clubs** }\end{array}$ & Midday meals & 5 & Protein, energy \\
\hline $\mathrm{F}$ & $\begin{array}{l}\text { Convalescent home for a London } \\
\text { hospital, about } 4 \circ \text { patients and } \\
\text { 15 staff }\end{array}$ & $\begin{array}{l}\text { Single meals: break- } \\
\text { fast, midday and } \\
\text { evening }\end{array}$ & 12 & Protein, energy \\
\hline Q & Nurses' home of a London hospital & $\begin{array}{l}\text { Single meals: break- } \\
\text { fast, midday and } \\
\text { evening }\end{array}$ & I3 & $\begin{array}{l}\text { Protein, energy, } \\
\text { chemical score }\end{array}$ \\
\hline $\mathrm{E}$ & $\begin{array}{l}\text { Galley of a seagoing merchant ship, } \\
55 \text { on board } \uparrow\end{array}$ & Whole days' intakes & 54 & $\begin{array}{l}\text { Protein, energy, } \\
\text { fat, iron }\end{array}$ \\
\hline
\end{tabular}

\section{Statistical methods}

There are a number of possible ways of comparing calculated $(c)$ and analytical $(a)$ values, such as:

(I) Calculation of the coefficient of correlation between $a$ and $c$. A high coefficient would indicate whether there is a consistent linear relationship between $a$ and $c$, but does not describe the relationship further. Thus if the value of $a$ were consistently half that of $c$, a high correlation coefficient would still result.

(2) Calculation of the mean value of $a$ and of $c$, with a test of the significance of the difference between these mean values ( $t$ test). The disadvantage of this test is that, if the variance of both $a$ and $c$ is great, large differences between the mean values appear non-significant, in spite of very large differences between individual paired values of $a$ and $c$.

(3) Calculation of individual differences $(a-c)$ followed by a $t$ test, which determines whether the mean difference diverges significantly from zero. If this is so, there will be a consistent tendency for calculated values to under- or over-estimate intake. 
(4) Calculation of the range of the $90 \%$ confidence limits for these differences; that is, the range within which $90 \%$ of the differences lie.

We have found (3) and (4) to be the most useful methods for assessing our data, but we have also given (I) and (2), to facilitate comparison with other published work.

\section{RESULTS}

The results of the comparison are summarized in Tables 3 and 4 and Fig. $x$. ('Table 3 may be compared with Table I; further comparisons are shown in 'Table 4.)

\section{Chemical score}

In the thirteen diets analysed, chemical score calculated from food tables agreed well with score estimated from the analytical values for total sulphur content.

Table 3. Distribution of differences between calculated (c) and analysed (a) values for the nutrient content of meals and diets (this study)

\begin{tabular}{|c|c|c|c|c|c|}
\hline \multirow[b]{2}{*}{ Nutrient } & \multirow[b]{2}{*}{ Series* } & \multicolumn{2}{|c|}{$\begin{array}{l}\text { No. and } \% \text { of diets analysed } \\
\text { falling within each range } \\
\text { of } \% \text { difference } \\
\qquad\left(\frac{c-a}{a} \times \text { roo }\right)\end{array}$} & \multirow{2}{*}{$\begin{array}{l}\text { Total no. } \\
\text { in } \\
\text { group }\end{array}$} & \multirow{2}{*}{$\begin{array}{l}\text { Correlation } \\
\text { coefficient } \\
\text { (cv. a) }\end{array}$} \\
\hline & & $0-9 \%$ & $10-19 \%$ & & \\
\hline Energy (kcal) & $\mathrm{S}, \mathrm{F}, \mathrm{Q}, \mathrm{E}$ & $\begin{array}{l}8(27 \%) \\
\text { II }(20 \%\end{array}$ & $\begin{array}{r}3(10 \%) \\
16(30 \%)\end{array}$ & $\begin{array}{l}30 \\
54\end{array}$ & $\begin{array}{l}0.82 \\
0.84\end{array}$ \\
\hline Chemical score $(\%)$ & $\mathrm{S}, \mathrm{F}, \mathrm{Q}, \mathrm{E}$ & $\begin{array}{l}10(33 \%) \\
25(46 \%) \\
12(92 \%)\end{array}$ & $\begin{array}{c}\text { I }(3 \%) \\
\text { I }(31 \%) \\
0(0 \%)\end{array}$ & $\begin{array}{l}30 \\
54 \\
13\end{array}$ & $\begin{array}{l}0.68 \\
0.74 \\
0.87\end{array}$ \\
\hline Fat $(g)$ & $\mathbf{E}$ & $14(26 \%)$ & $4(7 \%)$ & 54 & 0.65 \\
\hline Iron (mg) & $\mathrm{E}$ & $7(13 \%)$ & $I_{4}(26 \%)$ & 54 & 0.49 \\
\hline
\end{tabular}

\section{Protein}

Calculated values for protein were better correlated with analytical valucs in whole days' intakes than in single meals. There was a wide range of differences, but the mean difference was not significant, indicating that the food table did not have a 'high' or ' $l o w$ ' bias. 'The range of the $90 \%$ confidence limits for percentage difference was higher for single meals than for whole days' intakes. 'The results from series $E$ (which consisted of three $3 \mathrm{~d}$ intake records from six men) were grouped into eighteen $3 \mathrm{~d}$ average intakes, and when this was done the range of the confidence limits fell from $\pm 43 \%$ to $\pm 34 \%$.

\section{Energy}

As for protein, there was better correlation between $a$ and $c$ for whole days' energy intakes than for single meals; the mean difference between the two estimates was significant, $c$ being higher than $a$, indicating that the food table has a 'high' bias, and this led to a consistent overestimate of daily energy intakes of the order of $20 \%$. The range of the $90 \%$ confidence limits was slightly less than for protein. 
Vol. 27

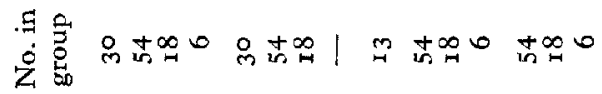

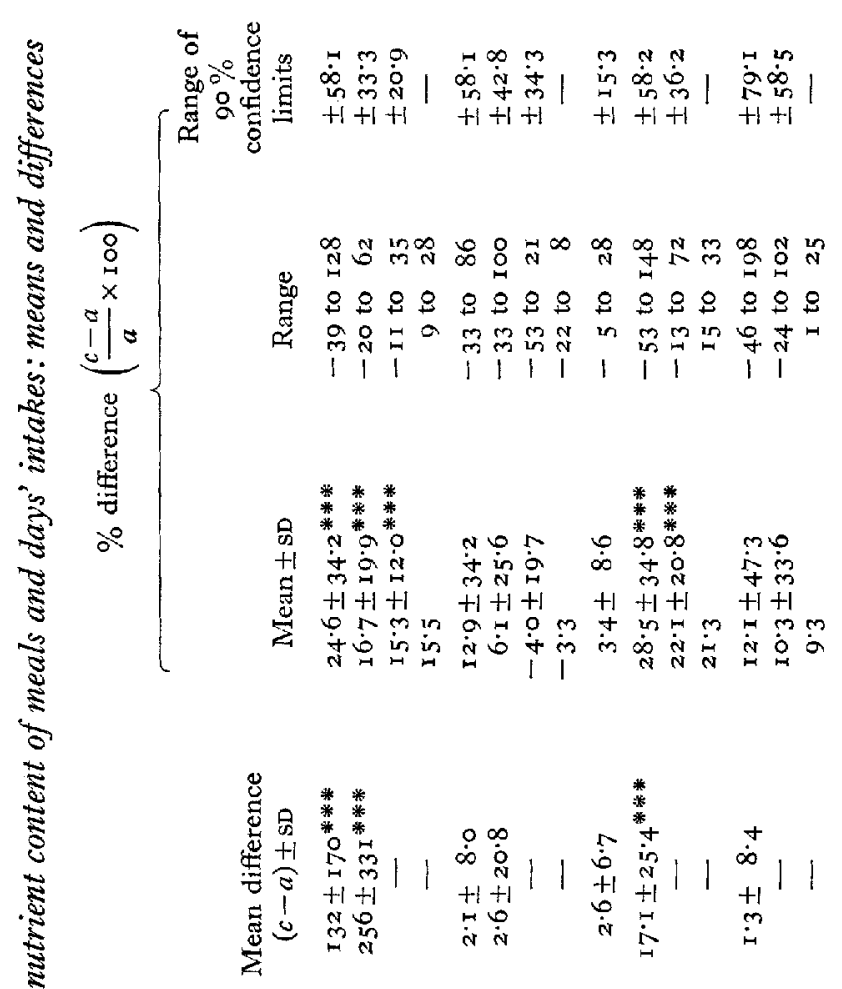

s. 


\section{Fat}

As might be expected, the results for fat presented a slightly exaggerated version of the results for energy. There was a wider range of differences and a lower correlation coefficient. The mean difference between calculated and analysed intake was significant, $c$ being greater than $a$, indicating a 'high' bias in the food table.
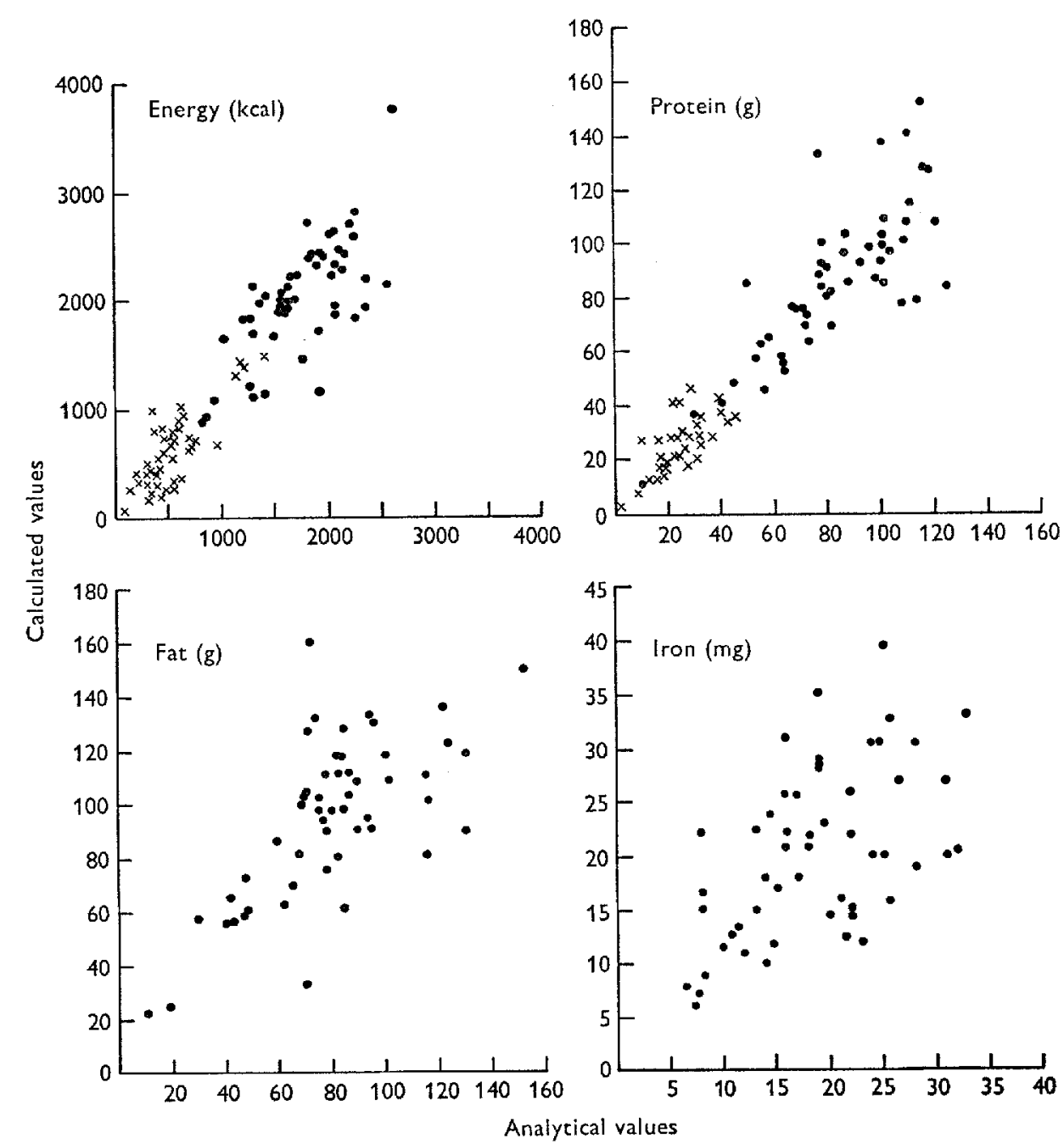

Fig. I. Calculated and analytical values for the energy, protein, fat and iron content of meals $(x)$ and days' intakes $(\varphi)$.

\section{Iron}

There was a wide range of differences and a low correlation between calculated and analysed intake; but the mean difference between calculated and analysed intakes was not significant. 


\section{Number and type of food items}

It might be supposed that the meals or days' intakes which contained fewer items of food, or fewer multi-ingredient cooked foods, would be those in which the calculated and analytical values corresponded more closely. The only instance in which any sign of such a relationship could be found was in energy intakes, where there was a moderate correlation $(r=0.54)$ between the total number of food items eaten and the absolute difference between calculated and analysed intakes. When differences were expressed as percentages of the mean intake this relationship disappeared: in fact percentage differences were lower in whole days' intake than in single meals.

Table 5. Frequency of occurrence of certain foods in intake group ' $E$ ' (see Table 2) in relation to the differences between thirty-two calculated $(c)$ and analysed (a) fat intakes

Average no. of certain foods per day's intake

\begin{tabular}{|c|c|c|c|c|c|c|c|}
\hline $\begin{array}{l}\text { No. of } \\
\text { intakes }\end{array}$ & $\begin{array}{c}\text { Absolute } \\
\text { difference, } \\
c-a \\
\text { (g fat) }\end{array}$ & $\begin{array}{c}\text { Fried } \\
\text { egg }\end{array}$ & $\begin{array}{l}\text { Fried meat } \\
\text { including } \\
\text { bacon, and } \\
\text { fried fish }\end{array}$ & $\begin{array}{l}\text { Roast, } \\
\text { sauté or } \\
\text { fried } \\
\text { vegetables } \\
\text { or bread }\end{array}$ & $\begin{array}{l}\text { Gravy and } \\
\text { soup }\end{array}$ & $\begin{array}{l}\text { Thick } \\
\text { sauces }\end{array}$ & Chops \\
\hline 6 & $0-10$ & 0.7 & $I \cdot 2$ & 0.9 & 0.9 & 0.7 & 0.7 \\
\hline IO & II $-\mathrm{I} 4$ & $I \cdot I$ & $I \cdot I$ & $x \cdot 7$ & 0.9 & 0.9 & $0 \cdot 3$ \\
\hline I 3 & $25-50$ & $1 \cdot 3$ & $1 \cdot 8$ & $1 \cdot 5$ & 0.9 & $I \cdot 3$ & 0 \\
\hline 3 & $50+$ & 0.7 & $2 \cdot 6$ & $2 \cdot 3$ & $2 \cdot 7$ & 0.5 & $\mathrm{I} \cdot 3$ \\
\hline
\end{tabular}

Intakes containing curry, pilau, fried rice and cheese sauce have been excluded (see below).

It might also be supposed that if a meal or days' intake contained several foods with a high fat content, or several foods which had been cooked in fat, then discrepancies between calculated and analytical values for fat and energy intakes would be high. From examination of the fifty-four records in series $\mathrm{E}$, it was possible to identify foods which, when present in the meals, had a consistent effect on the magnitude of the discrepancy for fat. The fat contents of curry, fried rice, pilau and cheese sauce were evidently underestimated from the food composition table, as it was only when they occurred in a meal that the analytical values exceeded the calculated ones. When meals containing these foods had been excluded, it could be seen that the fat content of six main groups of foods was overestimated from the food table, so that the oftener they occurred, the higher were the differences. This is shown in Table 5, where it can be seen that fried foods, some foods such as soup and sauces which are made with fat, and chops (in which the proportions of fat, lean meat and bone vary considerably) make major contributions to 'high' difference in fat intakes. Foods which were expected to have this effect, but do not show it, were meat stews, casseroles and similar dishes, pastry, and pork other than pork chops.

There was a fairly high positive correlation $(r=0.8 \mathbf{1})$ between the difference between calculated and analytical values for fat and for total energy in series $E$, and it seems probable that the presence of the above foods contributes to large differences in estimates of energy intake as well. 


\section{DISCUSSION}

In making this comparison between our calculated and analytical values we are mainly considering differences between pairs of calculated and analytical values. Comparisons between mean analytical and mean calculated values are less useful because of their large variance (for example, the coefficient of variation of single days' fat intakes was $35 \%$ ).

For protein and iron, the distribution of differences in our results was similar to that found by other investigators, if we exclude those who were working under the controlled conditions of a metabolic ward kitchen. Moreover, positive and negative errors appeared to be equally distributed, so that there was not a consistent tendency for protein or iron intakes to be over- or under-estimated. The range of difference for iron was very wide, reflecting the large variation in the mineral content of foods.

For fat and energy intakes, however, we found greater differences than did most other workers, and there is a consistent and significant tendency for the calculated values to be higher than the analysed, and for intakes to be overestimated by calculation. This can be related to the consumption of complex multi-ingredient dishes, and those with a high and variable fat content.

The range of differences would be smaller for individuals who chose 'simple' diets with few foods, especially if multi-ingredient dishes and fried foods were used infrequently. This is because one of the most difficult quantities to estimate in assessing the nutrient value of cooked foods is the fat content of fried foods, since it depends not upon a standard recipe, but entirely on the procedure adopted by the cook. Similarly, in making soups and sauces which are based on a fat-flour mixture with the addition of stock, the cook is free to vary the water content, and consequently the fat content, of the food within very wide limits depending on the materials at his disposal, which may vary from day to day. Grant (1944) showed that there could be a $77 \%$ difference between the energy contents of meat stews prepared from different recipes, and it would not be surprising to find an even greater variation in dishes such as fried eggs or soups which are not prepared from a fixed recipe under ordinary catering conditions. Unfortunately, the method (advocated by Grant and widely used in surveys) of obtaining the recipe for the dish and calculating intakes from the ingredients, cannot easily be applied to such dishes. Nor would it be particularly useful to do spot analyses of these foods, unless this was done daily. Considerable variation in the fat content and hence in the energy content of many cooked foods has therefore to be accepted as inherent in weighed dietary surveys.

This being so, it is useful to know the magnitude of the variance which should be expected in the results of surveys done under the conditions, and in the type of institutions, which we have described. In Table 4 we have given the range of the $90 \%$ confidence limits for percentage differences on the single days' intakes; that is, the range within which $90 \%$ of percentage differences lie. These limits were wide; for instance, in estimates of single days' calorie intake, the $90 \%$ confidence limits were $\pm 33 \%$. However, most weighed dietary surveys are done over 3,4 or $7 \mathrm{~d}$, and it 
might be expected that a better estimate of intake would be obtained over several days than during I d only.

The results for series $E$, which consisted of three $3 \mathrm{~d}$ intakes for six subjects, was also grouped into $3 \mathrm{~d}$ and $9 \mathrm{~d}$ averages, and these are shown in Table 4 in the same way as the single days' intakes. As the number of days grouped together increases, although the differences for energy and fat remain significant, the range of the percentage differences becomes less. 'Thus, the range of the $90 \%$ confidence limits is less for $3 \mathrm{~d}$ averages than for single days' intake. For a $3 \mathrm{~d}$ survey the confidence limits for energy would be $\pm 21 \%$, and for protein, $\pm 34 \%$. Although we have insufficient values to test the effect of 7 or $9 \mathrm{~d}$ grouping, we consider that further reductions in the range of the confidence limits would be seen if intakes were grouped in this way. The series ' $\mathrm{E}$ ' results suggest that in $7 \mathrm{~d}$ individual weighed-intake surveys, the range of error attributable to the use of food composition tables would be of the order of $\pm 20 \%$ for protein and energy, and $\pm 50 \%$ for iron.

It is of interest that the dietary energy intake of eight out of a group of eleven elderly women living in a Local Authority Home was within $\pm 20 \%$ of measured daily energy expenditure, the diets having been measured for $7 \mathrm{~d}$ (Salvosa, Payne \& Wheeler, 1971). The discrepancy between their energy expenditure and calculated intake was thus of the same order as the range which we have found for differences between calculated and analysed intakes.

In some instances it would be useful to be able to define the least difference - for example, in the energy intakes of two groups - which could be considered significant, taking into account the errors of measurement. Our results suggest that the variation due to the use of food composition tables is $\pm 20 \%$. The variation of individual energy intake is approximately $\pm 10 \%$ from one week to another (Marr, 1971), so a difference of less than $\pm 30 \%$ between the energy intakes of two groups could not necessarily be regarded as significant unless all members of the groups were eating from the same menu.

Miss Norah Griffiths and Mr A. N. Chorlton helped us with the collection and analysis of some of the food samples. The surveys from which we derived our data were supported by grants from the Nuffield Provincial Hospitals Trust and the Esso Petroleum Company, and carried out under the direction of Dr T. P. Eddy.

\section{REFERENCES}

Bransby, E. R., Daubney, C. G. \& King, J. (1948-9a). Br. F. Nutr. 2, 89.

Bransby, E. R., Daubney, C. G. \& King, J. (1948-9b). Br. F. Nutr. 2, 232.

Collins, K. J., Eddy, T. P., Hibbs, A., Stock, A. L. \& Wheeler, E. F. (1971). Br. F. ind. Med. 28, 246.

Eagles, J. A., Whiting, M. G. \& Olson, R. E. (1966). Am. F. clin. Nutr. I9, I.

Exton-Smith, A. N. \& Stanton, B. R. (1965). Report of an Investigation into the Dietary of Elderly Women Living Alone. King Edward's Hospital Fund for London.

Grant, M. (1944). Nature, Lond. I54, 485 .

Groover, M. E. Jr, Boone, L., Houk, P. C. \& Wolf, S. (1967). F. Am. med. Ass. $201,8$.

Hegarty, P. V. J. (r966). Investigations of anaemogenic diets. PhD Thesis, University of London.

Krauze, S., Bożyk, Z. \& Zaniewska, A. (1965). Roczn. panst. Zakl. Hig. 16, ı6 I.

Matr, J. W. (1971). Wld Rev. Nutr. Diet. r3, 105. 
McCance, R. A. \& Widdowson, E. M. (1960). Spec. Rep. Ser. med. Res. Coun. no. 297.

Miller, D. S. \& Donoso, G. (1963). F. Sci. Fd Agric. 14, 345.

Miller, D. S. \& Payne, P. R. (1959). Br. F. Nutr. 13, 501.

Orr, M. L. \& Watt, B. K. (1967). Home Econ. Res. Rep. no. 4. Washington, DC: United States Department of Agriculture.

Pellett, P. L. \& Eddy, T. P. (1964). Br. Y. Nutr. 18, 567.

Pellett, P. L. \& Wheeler, E. F. (1965). Proc. Nutr. Soc. 24, xli.

Salvosa, C. B., Payne, P. R. \& Wheeler, E. F. (1971). Am. F. clin. Nutr. 24, I164.

Takagi, K. \& Sato, S. (1969). F. Sci. Labour 45, 304 .

Whiting, M. G. \& Leverton, R. M. (1960). Am. F. publ. Hlth 50, 8I 5 .

Widdowson, E. M. \& McCance, R. A. (1943). Lancet i, 230.

Wootton, I. D. P. (1958). Biochem. F. 68, 197. 